\title{
Comparison the Views of Classical and Contemporary Fiqh Ulama on the Use of Zakat Maal for the Development of Educational and Da'wah Institutions
}

\begin{abstract}
Khusnul Fikriyah ${ }^{1}$
${ }^{1}$ Fakultas Ekonomika dan Bisnis, Universitas Negeri Surabaya

Abstract: Nowadays, zakat paid by muzakki is channeled through an educational empowerment model, including scholarships for poor children. In addition to scholarships, the empowerment model also improved, zakat funds are also used for the development of Educational and Da'wah Institutions, including for schools, campuses, dormitories, and mosques. In At-Taubah 60, there is no mention of the Board of Education and Da'wah included in the asnaf who are entitled to receive zakat. Thus, the question arises as to how the legal position of the use of zakat funds for the benefit of the development of educational institutions and da'wah, whether the law is allowed according to sharia or not. This study used a qualitative library research method. The conclusion of this article states that zakat funds are allowed for the construction of educational and da'wah institutions, by using the reason for the "generality of interpretation" of the word sabilillah (في سبيل الله in At-Taubah: 60 as one of the parties entitled to receive zakat. If the zakat funds for asnaf sabilillah still use the classical meaning, which means only for war, then the scope will be very narrow. In addition, at this time, jihad, which means war on the battlefield no longer exists, because it is considered a violation of human rights, and even if this kind of war is still being financed by the state.
\end{abstract}

Keywords: zakat maal; development; educational institutions; da'wah institutions; fiqh expert perspective

*Corresponding author: khusnulfikriyah@unesa.ac.id

Received: May 07, 2021; Accepted: May 25, 2021; Published: June 15, 2020

\footnotetext{
Abstrak: Saat ini zakat yang dibayarkan oleh muzakki juga disalurkan melalui model pemberdayaan pendidikan, termasuk pemberian beasiswa bagi anak-anak miskin. Selain beasiswa, model pemberdayaan kini juga ditingkatkan, dana zakat juga digunakan untuk pengembangan Lembaga Pendidikan dan Dakwah, termasuk untuk sekolah, kampus, asrama, dan masjid. Sedangkan pada At-Taubah 60 tidak disebutkan Lembaga Pendidikan
} 
dan Dakwah termasuk dalam asnaf yang berhak menerima zakat. Maka dari fenomena tersebut, muncul pertanyaan bagaimana kedudukan hukum penggunaan dana zakat untuk kepentingan pengembangan lembaga pendidikan dan dakwah, apakah hukum diperbolehkan menurut syariah atau tidak. Makalah ini menggunakan metode penelitian pustaka dengan pendekatan kualitatif. Kesimpulan artikel ini menyatakan bahwa dana zakat diperbolehkan untuk pembangunan lembaga pendidikan dan dakwah, dengan menggunakan alasan "generalitas tafsir" dari kata sabilillah (في سبيل الله di At-Taubah: 60 sebagai satu pihak yang berhak menerima zakat. Dan apabila dana zakat untuk asnaf sabilillah, masih menggunakan pemaknaan klasik yang berarti hanya untuk perang, maka cakupan akan sangat sempit. Ditambah lagi saat ini jihad yang dimaknai perang di medan pertempuran sudah tidak ada lagi, karena dianggap pelanggaran HAM, dan kalau pun masih ada peperangan semacam ini dibiayai negara.

Kata kunci: Zakat Maal; Pembangunan; Lembaga Pendidikan; Lembaga Dakwah; Perspektif Ulama Fiqh

\section{INTRODUCTION}

Zakat is worship, which includes two-dimensional bonds, regulating the bonds between humans and God (habluminallah), and the bonds between fellow humans (habluminannas). Zakat is believed to be a solution to the problem of poverty, because in Islam, zakat is a solution to the distribution of welfare, where people who are categorized as rich according to sharia (muzakki) help those who are poor and are classified as asnaf (mustahiq). Zakat is a form of worship reflected in the pillars of Islam, which is the third pillar of Islam. In Islam, it is also forbidden to hoard assets, as stated in QS. Al Hasyr verse 7.

Zakat is a part of worship in the field of property (Ma'liyah worship), which is collected from the rich according to the Islamic category (muzakki), and distributed to the poor, who are included in eight asnaves (mustahiq). The zakat issued seems to be accepted by Allah, even though it is physically received by the asnaf group (Qadir, 1998).

The distribution of zakat funds by the Amil Zakat institution is currently in general through the empowerment model. The majority of Amil Zakat Institutions (LAZ) develop the following four empowerment models: 1) empowerment in the economic sector, 2) empowerment in the health sector, 3) social and humanitarian (disaster management), and 4) empowerment in the field of education (Fikriyah \& Ridlwan, 2018).

A common phenomenon today, zakat paid by muzakki is also channeled through an educational empowerment model, including scholarships for poor children who cannot afford to pay for education. Quoting from research (Hakim et al., 2014) In addition to scholarships, the empowerment model is now also growing, zakat funds are also used for the development of Educational and Da'wah Institutions, including for schools, campuses, dormitories, and mosques. If quoting in the Al Quran AtTaubah verse 60 the allotment of zakat is for eight asnaf, as stated in the verse which means: "In fact, zakat-zakat is only for the needy, the poor, the administrators of zakat, the Mu'allaf who was persuaded by his heart, to (free) slaves, people in debt, for the way of Allah and those who are on their way, as a provision which is required by Allah And Allah is All-Knowing, Most Wise. " 
The meaning of the At-Taubah verse 60 verse emphasizes the parties who are entitled to receive zakat funds. Educational and Da'wah institutions were not included in the study. From this phenomenon, the question arises as to what is the legal position of the use of zakat funds for the development of educational institutions and da'wah, whether the law is permissible according to sharia or not. An institution is defined as an agency (organization) whose purpose is to carry out a scientific investigation or carry out a business. Education is defined as the process of changing the attitudes and behavior of a person or group of people in an effort to mature humans through teaching and training efforts, the process, the way, and the act of education. Thus, it can be concluded that educational institutions aim to change attitudes and behaviors through teaching and training efforts. The existing forms of education in Indonesia can be grouped into two major groups: formal education (e.g., schools and campuses) and non-formal (e.g., Islamic boarding schools/pesantren, courses, the Koran, tutoring, and many more).

Da'wah is defined as the broadcast of religion and its development in the community; a call to embrace, study, and practice religious teachings. If we draw a conclusion, a da'wah institution is an organization that broadcasts religion and its development in the community. The purpose of the Da'wah Institute is to spread the religion of Allah to invite goodness. Examples of da'wah institutions include mosques, Mushollah, zakat organizations, Islamic boarding schools (pesantren), and many more.

In several previous studies, many sources of zakat maals have been channeled for the construction of educational facilities and infrastructure, such as professional zakat from the Ministry of Religion (Mukhsapak \& Zahid, 2019), professional zakat, and stock zakat (Arif, 2019). Many zakat maals have been distributed for the construction of mosques and da'wah institutions (Zainuddin, 2017), (Maimun, 2012), (Listari, 2017), (Sinta \& Isbah, 2019). And from the many studies conducted by following the opinions of classical fiqh experts and contemporary fiqh experts, some have concluded that zakat funds for asnaf fi sabilillah can be channeled for the development of educational institutions and da'wah institutions (Hayati, 2012), (Rambe \& Afdhal, 2008), and there are who argue that it is not allowed (Zainuddin, 2017). In this article, the author tries to collaborate on everything that is the basis for determining the law in Islam, namely using the basis of the Al-Quran and AsSunah, books of fiqh, tafseer, and zakat books. Then, we compare the opinions of classical and contemporary fiqh experts and link them with the opinions of zakat experts and modern zakat books.

\section{RESEARCH METHODS}

This study used a qualitative library research method. The discussion presented is based on the references examined through the verses of the Koran, hadith, books of fiqh, tafsir, and zakat books. From these references, the opinions and arguments of the ulama are quoted along with the arguments they make the basis of these arguments, as well as the opinions of contemporary zakat experts, after which a conclusion is drawn. 
RESULTS AND DISCUSSION

People who are entitled to zakat funds as stated in the Word of Allah SWT Q.S. AtTaubah, 9: Verse 60 (Al-Quran, n.d.):

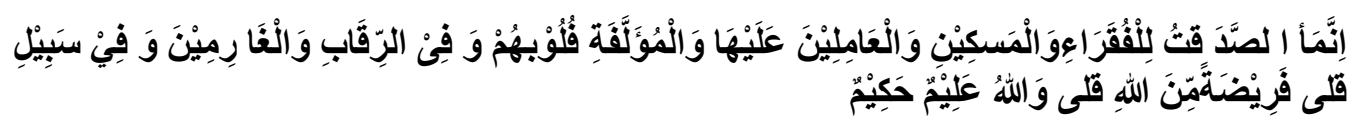

Meaning: "In fact, zakat is only for the needy, the poor, amil zakat, whose heart has softened (converts), to (liberate) my slave, to (free) people who are in debt, for the way of Allah and for those who are currently in debt. travel as an obligation of Allah. Allah is All-Knowing, All-wise'. (Surah At-Taubah 9: Verse 60).

In that verse, there is an indication of understanding that the zakat that has been collected is not given to all ashnaf, but is prioritized to certain ashnaf who are in dire need. Abu Hanifah said that zakat should not be given to other than the eight ashnaf, but it can be chosen from among the eight ashnaf (Yahya, n.d., p. 192). Quoted from (Tafsir Al-Madinah Al-Munawwarah /Markaz Tadzhim Al-Quran Di Bawah Pengawasan Syaikh Prof. Dr. Imad Zuhair Hafidz, Professor Fakultas AlQuran Universitas Islam Madinah., n.d.) it can be explained that people entitled to receive zakat are:

1. Needy person: One who has nothing; a person whose life is very miserable, and he cannot meet the necessities of life, because he does not have wealth and energy.

2. Poor people: people whose lives are not enough, but do not show poverty and do not beg. Having assets and manpower, but in a condition that is still lacking.

3. Zakat administrator (Amil): A person/party appointed and entrusted with the task of the ruler/state to collect zakat funds from muzakki and distribute it to mustahiq.

4. Muallaf: People who embrace a religion other than Islam and are persuaded by their hearts so that they hope to convert to Islam as well as people whose faith is still weak, because they have just converted to Islam, including those who convert to Islam because they hope to be given zakat.

5. To liberate/free slaves (riqab), the zakat is used to buy slaves, to be freed, and freeing Muslims who are under enemy control/are being held captive by infidels.

6. People who have debts (gharimin): people who are forced to go into debt for interests that are not prohibited by religion and not because they are extravagant, then that person is unable to pay them. There are also people in debt whose goal is for the unity of Muslims and for the propagation of Islamic development, they are allowed to pay it with zakat, even though that person is in a condition of being able to pay it.

7. People who walk in the way of Allah (sabilillah) are used to defend Islam and Muslims. Among them are people who are on the battlefield and also on standby at the border, giving them their share of zakat assets is to fulfill their needs during war and guard them even though they are classified as capable, or even part of the muzakki. 
8. A person who is safe (Ibn sabil): that is, a trip that is not prohibited by Sharia, and on his way he experiences misery, or a person who is on his way back to his house experiences a lack of supplies, so that it is difficult to return, he is entitled to a share of zakat assets even though he is a relatively capable person. In that verse, the word إنما (actually only) is to limit the recipients of zakat, and the construction of educational institutions and da'wah is not included in these 8 groups. The discussion consists of pro and contra opinions regarding the use of zakat for the development of educational institutions and da'wah, which are then compared between the opinions and arguments of the ulama along with the arguments they put forward.

Sabilillah is defined as a way to achieve the pleasure of Allah (Qardawi, 2000). Abu Yusuf, who belongs to the Hanafi group, explained the meaning of sabilillah for volunteers who were depleted of supplies. In this opinion, war volunteers are allowed to obtain zakat, even though they are not classified as needy or poor, and still have the ability to do business, it is feared that if they do their business, they will be left behind from jihad. In line with this opinion, Ibn Zaid and Sheikh Abdul Aziz bin Baz when interpreting it as "People who fight in the way of Allah'."

Madzhab Maliki agrees that sabilillah is related to warfare, or jihad, and things that have the same meaning, such as guard posts (Qardawi, 2000). It is permissible to give zakat to a mujahid even though he is rich, because this zakat giving is not because of his poverty but because of his jihad. The majority of Madzhab Maliki also allow the use of zakat for war, not specifically for the person who is fighting, but also for war purposes that are not one's own. For example, the construction of forts, guard posts, etc.

According to the Madzhab Syafi'i of thought, sabilillah are war volunteers who do not receive regular allowances from the government; they go to war if they are in good condition, healthy, and strong, and if they are not doing their job. Ibn Hajar argues that the term sabilillah means the path that brings someone to the pleasure of Allah, because in the past, the term sabilillah was often used for jihad (war), so sabilillah was later used for those who fought. Furthermore, the Madzhab Hanbali explains that the state is allowed to buy a horse from zakat assets, then leave it to someone to be used for war, even though the person who is fighting is a muzakki (Qardawi, 2000).

Sabiq states that Sabilillah means jihad or fighting in the way of Allah. And the people who get the zakat share are soldiers who are not paid by the government, namely volunteer soldiers (Sabiq, 1977).

In contrast to the Madzhab Hanafi, hambali, and Shafi'i, according to Shadiq Hasan Khan, although interpreting sabilillah is the same as the opinion of these classical ulama, namely the way of Allah. "However, jihad, although it is the greatest way to Allah, there is no reason that this section is only dedicated to jihad' (Qardawi, 2000). Sadiq Hasan Khan's opinion implicitly states that Sabilillah has no limits. This is also in line with the opinion of Abu Bakr Ahmad Al-Jashash, who stated that the definition of sabilillah was initially understood by the majority of scholars as jihad fi sabilillah, but in subsequent developments sabilillah is defined in addition to war in the way of Allah, also includes all programs and activities that provide benefits to the community. Muslims, such as building mosques and their welfare, 
madrasas, hospitals, building forts, including taking care of corpses (Ahmad AlJashash, 1993).

This is contrary to Wahbah Zuhaili's opinion, who states that it is not permissible to give zakat to other than those mentioned by Allah in the Qur'an such as building mosques, bridges, reservoirs, digging rivers, repairing roads, shrouding corpses and so on, all of which do not show ownership. The reason is because those who are entitled to receive zakat have been limited by Allah to only eight asnaves. Therefore, it should not be shared with other (Musthafa Az-Zuhaili, n.d.).

According to Rasyid Ridha in Tafsir Al-Manar, sabilillah is for the general interest of Muslims, which is used to uphold religious affairs and the state, and not for individual interests. The most important thing and must be prioritized is for war preparation, providing the necessary weaponry, supplies, and food for the army, and other war preparations. Including the commonness of sabilillah is building a hospital for soldiers who were injured during the war, as well as other public benefits, building roads, and repairing them. The most important thing to pay for sabilillah at this time is to prepare the da'i who call to the path of Islam, to send them to infidel countries, to make ends meet while spreading Islam (Qardawi, 2000). This opinion of Rasyid Ridha can also be used as the basis for allowing zakat for the development of educational and da'wah institutions, apart from being of benefit, educational and da'wah institutions also aim to call to the path of Islam and uphold the religion of Allah. However, it is still preferred to use it for purposes on the battlefield.

According to the mazhab Ja'fari sabilillah are all actions in order to get closer to Allah, such as the pilgrimage, for example, or for the common good, such as jihad, building roads, and bridges. This is also corroborated by Madzhab Zaidi's opinion that all things are the path of goodness, so they can be categorized as sabilillah. Although sabilillah is often used in one of its madlul, namely jihad, because it often happened at the beginning of Islam, there is no real meaning of u'ruf, where sabilillah will remain in its first meaning, namely all kinds of goodness in accordance with the general and special benefits, unless specifically determined by the argument (Qardawi, 2000). The development of educational institutions and da'wah is certainly aimed at mutual benefit, if you quote from the views of the Madzhab Ja'fari and Zaidi, zakat is allowed for the development of educational institutions and da'wah, because its main purpose is for the benefit. Part of this development will also be used for asnafs; for example, children of needy and poor parents can go to school and get education at the educational institution. In fact, what happens a lot in the field of educational institutions established with the help of zakat, aims to provide free and proper education facilities for children whose parents cannot afford it. Children from the well-off families were charged with education fees.

In Syarah al-Azar, Imam Al-Hadi's opinion is that, in this section, it is permissible to use the excess of zakat funds for the common benefit of Muslims. In line with this opinion, Abu Talib argued that "actually this part is used for the common good, when fuqara no longer needs it. However, if at the same time there is a fuqara who is in need, then fuqara is more entitled to the zakat (Qardawi, 2000). In line with the opinion of Abu Talib, Al-Lajnah Ad-Daimah also said that this is the opinion 
of the majority of commentators, hadiths, and fiqh experts. It should be emphasized that if there are no longer people from the eight groups who need zakat funds, they can be used for the construction of public facilities such as mosques.

The opinion of Ath-Tabary says of Allah At-Taubah Verse 60, sabilillah means living in maintaining and maintaining the religion of Allah, the way of Allah, and what Allah has declared for his servants, by fighting the enemies of Allah, which is reflected in warfare against the enemy of Islam (Ath-Thabari, 2008). Ath-Thabari specifies that jihad is a war to fight against Allah's enemies. In line with Ath-Tabary, Ibn Hajar Al-Asqalany argued that the majority of ulama argued that the term sabilillah was intended only for Muslims who participated in battles on the battlefield, regardless of whether he was classified as rich or from the poor ( $\mathrm{Al}$ Asqalani, n.d.).

If we conclude from the four Madzhab, stating this sabilillah means jihad, or real war, by using an army, which moves to exalt the religion of Allah, which aims to spread the religion of Allah, so that no human will worship other than Allah. However, wars like this no longer exist and have not even existed for a long time. It is precisely the war that many Muslims face today is war with liars and parties who hate Islam with contempt, who no longer face it by fighting on the battlefield, but in other ways. For example, in October 2020, French President Emmanuel Macron insulted Allah's religion. In his speech, Macron stated his strategy against separatism. He is clearly targeting and stigmatizing the Muslim community. Macron also justifies such discrimination and confidently considers that Muslim imams in France need to receive local training. He plans to elaborate on religious extremism, political Islam, and Islam as a whole. In fact, he also said, "Islam is a religion that is experiencing a crisis today, all over the world"

It is impossible to face an enemy of Islam like this with warfare on the battlefield, but face it in other ways. For example, what many Indonesian ulamas recommend boycotting French products? Thus, such attacks can weaken a country's economy. Apart from that, Muslim figures in the world are doing the same thing. In order to fight against this enemy of Islam, those who signed the call for a boycott were Ahmad al-Raysuni, who is the Chairman of the International Union of Muslim Scholars, Muhammad al-Hassan al-Dodu, an Ethopian ulama, Al-Hassan AlKattani who is a part of from Moroccan ulama, Yusuf Al-Qaradawi, an Islamic theologian who came from Egypt, and Ihsan al-Utaibi, who is a Jordanian Muslim figure. Boycotts like this, for example, no longer require zakat funds to buy war equipment, but may require zakat to make new regulations, which are related to the termination of cooperation between countries (at the ruler/state level).

Another opinion from Oni Syahroni et al., which is stated in the book Fikih Zakat Contemporary, Oni Syahroni, revealed that the meaning of the word fi sabilillah is for war, for weaponry, and for eating during the war. However, war equipment is already in the state budget so Oni Syahroni makes an analogy of fi sabilillah in several examples: 1) the construction of a center for Islamic da'wah activities; 2) Establishment of publication facilities, for example the media which functions to provide information about Islam, and the media also acts as a medium that provides confirmation and at the same time dispels information defamatory of Islam; 3) Publishing and disseminating Islamic books; 4) Providing operational funds for da'i 
who preach outside their residence; 5) Giving appreciation to the mujahid who are struggling to uphold the Islamic treatise (Syahroni et al., 2019). From Syahroni's opinion, zakat funds can be used in the development of educational and da'wah institutions, in accordance with points 1 to 4 .

The opinion of Hasanah, author of the book Modern Zakat Management, defines sabilillah as a religious development program, which can mean very broadly. Thus, if the development of Educational and Da'wah Institutions aims to develop the religion of Allah, then it can certainly be included in this category, then the development of Educational and Da'wah Institutions is allowed to use zakat funds (Hasanah, 2020). This is in line with the thought (Listari, 2017) which states that this zakat should not be used for development funds, except for the construction of places of worship, because the construction of places of worship is included in the category of sabilillah. Even the results of the research (Sinta \& Isbah, 2019) state that the collaboration of Dompet Dhuafa, Rumah Zakat with the Yogyakarta Center for Mualaf Da'wah Institute (MCY) provides many benefits for many converts. The preaching institute for converts at the Yogyakarta center provides assistance to prospective converts from before saying the creed, studying religion (prayer, fasting, ablution, reading the Koran, etc.) to provide knowledge about usury and Islam in general. This is done so that the converts will be stronger and stronger in embracing Islam.

The opinion of Muhyiddin Khatib, the author of the Book of Fikih Zakat Reconstruction, states that sabilillah means in the way of Allah, where initially the term sabilillah was defined as fighting in the way of Allah, because at that time the term sabilillah was often juxtaposed with the term war jihad. However, if this meaning is still used at this time, the scope will be very narrow, especially now that war is considered a violation of human rights; therefore, sabilillah must get an expansion of meaning, especially regarding the recipient of zakat (asnaf). Expanding the meaning of the term sabililliah, especially with regard to the allocation of zakat funds for the development of human resources, to defend Allah's religion of Allah (Khatib, 2019). Khatib's opinion is in line with Supena's opinion in the Zakat Management Book. According to him, Sabilillah can be used for the purposes of a) Al Hukumah (implementation of the state or government system) that is intended for the interests of the people; b) protection of the security of citizens; c) enforcing legal justice for citizens as well as providing salaries for officials; d) construction and maintenance of public facilities and infrastructure; and e) other things that are consistently aimed at realizing the ideals of social justice and human welfare (Supena \& Darmuin, 2009).

\section{CONCLUSION}

Regarding the use of zakat funds for the development of educational and da'wah institutions, classical and contemporary fiqh ulama have different opinions, especially differences of opinion regarding sabilillah asnaffi, which are as follows:

- Some ulama understand that the meaning of fi sabilillah is to pay for the needs of war in the way of Allah. This group does not recommend zakat funds for the establishment of Educational and Da'wah Institutions. If there is no war, it is 
better if zakat is used for the needy and poor because they are considered more needy.

- Some ulama expand the meaning of sabilillah, which is all activities or activities aimed at fi sabilillah (in the way of Allah). This group of ulama allows zakat maal funds to be used for building mosques and other da'wah needs, on the basis of the broad meaning of sabilillah.

- Some ulama limits the meaning of sabilillah, because most of the costs of war are currently borne by the government (state); thus, the allocation of asnaf sabilillah may be used for other needs, such as the need for da'wah while considering proportionality and the principles of justice for other asnaves. This group of ulama concludes that zakat maal funds can be used for the development of educational institutions and da'wah if in the area of the mustahiqs. If the mosque is in a residential area where there are many wealthy people, it is not advisable to use zakat, but it is advisable to use other people's funds such as donations and waqf .

From the literature study that has been done, the writer argues that Sabil is a general term, covering all acts of sincerity that are used to attach to Allah. The author argues that it is permissible to use zakat for the construction of educational and da'wah institutions, by using the reason for the "generality of interpretation" of the word sabilillah (في سبيل الله in Q.S. [9]: 60 as one kind who is entitled to receive zakat. If the zakat funds for asnaf sabilillah still use the classical meaning, which means only for war, then the scope will be very narrow. In addition, at this time jihad, which means war on the battlefield no longer exists, because it is considered a human rights violation, and even if there is still this kind of war being financed by the state. Contemporary ulama and zakat experts Some argue that zakat funds for the benefit and upholding of Allah's religion are justified, and if sabilillah is interpreted as benefiting and upholding the religion of Allah, its scope will clearly be broader. This is because life undergoes changes and is very dynamic; therefore, the meaning of sabilillah must also be adapted to current relevant and appropriate conditions. Thus, the development of educational institutions and da'wah is allowed while still prioritizing the people who receive the benefits are people who are classified as eight asnaves.

\section{REFERENCES}

Ahmad Al-Jashash, A. (1993). Ahkam Al-Qur'an (Vol. 1-3). Dar Al-Fikr. Al Asqalani, I. H. (n.d.). Fathul Bari. Pustaka Azzam.

Al-Quran. (n.d.). Kementrian Agama. https://quran.kemenag.go.id/

Arif, K. M. (2019). Zakat Profesi dan Zakat Saham Perusahaan Solusi Anggaran Pendidikan Nasional. El-Arbah: Jurnal Ekonomi, Bisnis Dan Perbankan Syariah, 1(01), 82-96. https://doi.org/10.34005/elarbah.v1i01.531

Ath-Thabari, A.-T. (2008). Tafsir Ath-Thabari. Pustaka Azzam.

Fikriyah, K., \& Ridlwan, A. A. (2018). The Evaluation of Mustahiq EmpowermentBased Poverty Alleviation Program at Amil-Zakat Organizations. 
International Journal of Islamic Business and Economics (IJIBEC), 2(1), 10. https://doi.org/10.28918/ijibec.v2i1.1263

Hakim, A. R., Arif, S., \& Baisa, H. (2014). Peran Zakat dalam Pembangunan Pendidikan di Kota Bogor (Studi Kasus Pendayagunaan ZAkat Bidang Pendidikan Dompet Peduli Ummat Daarut Tauhid Cabang Bogor). AlInfaq: Jurnal Ekonomi Islam, 5(2), 30.

Hasanah, U. (2020). Manajemen Zakat Modern: Instrumen Pemberdayaan Ekonomu Umat. UIN Maliki Press.

Hayati, M. (2012). Peran Pemerintah dan Ulama dalam Pengelolaan Zakat dalam Rangka Usaha Penanggulangan Kemiskinan dan Peningkatan Pendidikan di Indonesia. Asas: Jurnal Hukum Ekonomi Syariah, 4(2), 9. https://doi.org/10.24042/asas.v4i2.1676

Khatib, M. (2019). Rekonstruksi Fikih Zakat: Telaah Komprehensif Fikih Zakat Pendekatan Teoritis dan Metodologi. Literasi Nusantara.

Listari, K. (2017). Zakat Sebagai Dana Pembangunan. Asy Syar'iyyah: Jurnal Ilmu Syar'iah dan Perbankan Islam, 2(2), 1-17. https://doi.org/10.32923/asy.v2i2.673

Maimun, M. (2012). Pendekatan Maqashid Al-Syariah Terhadap Pendistribusian Dana Zakat dan Pajak untuk Pembangunan Masjid. Asas: Jurnal Hukum Ekonomi Syariah, 4(2), 10. https://doi.org/10.24042/asas.v4i2.1674

Mukhsapak, \& Zahid, R. A. (2019). Optimalisasi Pemanfaatan Zakat Profesi Kantor Kementerian Agama Kabupaten Kediri Di Sektor Pendidikan. Jurnal Intelektual: Jurnal Pendidikan dan Studi Keislaman, 9(2), 159-172. https://doi.org/10.33367/ji.v9i2.1016

Musthafa Az-Zuhaili, W. (n.d.). Al-Fiqh Al-Islamiy wa Adillatuh (Vol. 2). Dar AlFikr.

Qadir, A. (1998). Zakat: Dalam Dimensi Mahdah dan Sosial. PT. Raja Grafindo Persada.

Qardawi, Y. (2000). Hukum Zakat. Litera AntarNusa.

Rambe, M. F., \& Afdhal, A. (2008). Kontribusi Zakat Maal dalam Mengembangkan Lembaga Pendidikan di Kota Medan. Jurnal Riset Akuntansi dan Bisnis, 8(2), 10. https://doi.org/10.30596/jrab.v8i2.450

Sabiq, S. (1977). Fiqh As-Sunnah. Dar Al-Kitab Al-Arabiy.

Sinta, A. D., \& Isbah, M. F. (2019). Filantropi dan Strategi Dakwah terhadap Mualaf: Kolaborasi Mualaf Center Yogyakarta, Dompet Dhuafa, dan Rumah Zakat di Yogyakarta. KOMUNIKA: Jurnal Dakwah dan Komunikasi, 13(1), 15-31. https://doi.org/10.24090/komunika.v13i1.2284

Supena, I., \& Darmuin, D. (2009). Manajemen Zakat. Walisongo Press.

Syahroni, O., Suharsono, M., \& Setiawan, A. (2019). Fikih Zakat Kontemporer. Rajawali Press.

Zainuddin, Z. (2017). Zakat Untuk Pembangunan Masjid. JURIS (Jurnal Ilmiah Syariah), 16(2), 233. https://doi.org/10.31958/juris.v16i2.975

Tafsir Al-Madinah Al-Munawwarah /Markaz Tadzhim Al-Quran di bawah pengawasan Syaikh Prof. Dr. Imad Zuhair Hafidz, professor fakultas AlQuran Universitas Islam Madinah. https://tafsirweb.com/3076-quran-suratat-taubah-ayat-60.html 